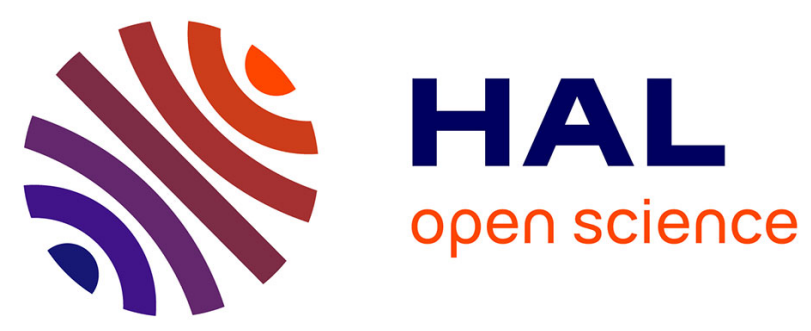

\title{
Gender stereotypes associated with vehicle driving among French preadolescents and adolescents
}

Marie-Axelle Granié, Elodie Papafava

\section{To cite this version:}

Marie-Axelle Granié, Elodie Papafava. Gender stereotypes associated with vehicle driving among French preadolescents and adolescents. Transportation Research Part F: Traffic Psychology and Behaviour, 2011, 14 (5), pp.341-353. 10.1016/j.trf.2011.04.002 . hal-00851153

\section{HAL Id: hal-00851153 https://hal.science/hal-00851153}

Submitted on 12 Aug 2013

HAL is a multi-disciplinary open access archive for the deposit and dissemination of scientific research documents, whether they are published or not. The documents may come from teaching and research institutions in France or abroad, or from public or private research centers.
L'archive ouverte pluridisciplinaire HAL, est destinée au dépôt et à la diffusion de documents scientifiques de niveau recherche, publiés ou non, émanant des établissements d'enseignement et de recherche français ou étrangers, des laboratoires publics ou privés. 


\section{Running head: Driving gender stereotypes among French preadolescents and}

\section{adolescents}

\section{Gender stereotypes associated with vehicle driving among French preadolescents and adolescents}

Marie-Axelle Granié (corresponding author)

Research Unit “Accident Mechanisms Analysis”

French National Institute for Transport and Safety Research

Chemin Croix Blanche

F-13300 Salon de Provence

France

marie-axelle.granie@inrets.fr

Phone number: (+00 33) 490577979

Fax number: (+00 33) 490568618

Elodie Papafava

Research Unit “Accident Mechanisms Analysis”

French National Institute for Transport and Safety Research

Chemin Croix Blanche

F-13300 Salon de Provence

France

Elsevier, Transportation Research Part F: Traffic Psychology and Behaviour

Volume 14, Issue 5, September 2011, Pages 341-353

http://dx.doi.org/10.1016/j.trf.2011.04.002

http://www.sciencedirect.com/science/journal/13698478 


\title{
Gender stereotypes associated with vehicle driving among French preadolescents and adolescents
}

\begin{abstract}
Gender differences in accidentology, notably on roads, are well documented and current research in social psychology tends to explain these differences by gender stereotypes, notably the association of risk-taking with social expectations concerning masculinity. To date, however, little research has explored gender stereotypes associated with vehicle driving. Beliefs about driving by men and women, as well as the effect of the age and gender of the perceiver, were explored using the free association method with 599 preadolescents and adolescents between 10 and 16 years of age. The results show that gender stereotypes are indeed associated with driving from the age of 10 . While the representation of male drivers is already stable at this age, the representation of female drivers appears to develop with age. Furthermore, there is a notable in-group serving bias, but only among girls. The results are discussed in terms of an essentialist representation of genders, in-group / out-group relations, age differences in gender stereotypes associated with driving, and practical consequences on driver's training and socialization to risk-taking.
\end{abstract}

\section{Keywords:}

Driving - gender stereotype - preadolescent - adolescent - gender

Gender stereotypes associated with vehicle driving among French preadolescents and adolescents 
Driving gender stereotypes among French preadolescents and adolescents

\section{Introduction}

Gender differences are well known in accidentology and manifest themselves very early in different types of accidents, and in particular in traffic injury rates. Men, and particularly young men, are involved in more crashes than young women. The difference between the sexes increases further from childhood, until it reaches a maximum among adults, in France, with 70 to $80 \%$ men among traffic fatalities between the ages of 15 and 59 (Assailly, 2001). This differential is not unique to France: in most Western countries, male drivers are 2-3 more likely to die in traffic crash than female drivers (Hanna, Taylor, Sheppard, and Laflamme, 2006; Nell, 2002; Özkan and Lajunen, 2005). Men reported more traffic violations (Lonczak, Neighbors, and Donovan, 2007), showed a lower level of normative motivation to comply with traffic laws (Yagil, 1998), tend to commit more violations, whereas female drivers tend to commit more errors (Aberg and Rimmö, 1998; Blockey and Hartley, 1995; Reason, Manstead, Stradling, Baxter, and Campbell, 1990). Males, especially younger ones, have greater self-assessed driving abilities (Farrow and Brissing, 1990; Özkan and Lajunen, 2006; Tronsmoen, 2008), felt safer while driving (Bergdahl, 2007) and used the automobile to enhance self-efficacy more than females (Farrow and Brissing, 1990). Young male drivers reported more driving injury risks behaviors and more traffic offences (Bina, Graziano, and Bonino, 2006; Harré, Field, and Kirkwood, 1996), have riskier driving attitudes and behaviors (Harré, Brandt, and Dawe, 2000) than young female drivers. Even the presence of male, compared to female, passengers seems to increase crash risks for young drivers (Lin and Fearn, 2003; Preusser, Ferguson, and Williams, 1998), especially among young male drivers (Doherty, Andrey, and MacGregor, 1998). More broadly, males display more risk taking behaviors than females (Byrnes, Miller, and Schafer, 1999). 
Men's tendency to take more risks has been generally explained in the past by a combination of biological and evolutionary theories. Thus, the classic explanation is that men have a higher level of sensation-seeking and take more risks because they produce more androgens (Social Issues Research Centre, 2004; Zuckerman, 1991) and/or because risk taking is a natural consequences of the basic requirements of males' community protection and gene dissemination (Daly and Wilson, 1987). Only recently has research begun to explore social environment influences on adults’ gender differences in risk-taking behavior.

Numerous psychologists indeed ascribe the male-female difference in risk-taking to gender roles and gender stereotypes (Byrnes, et al., 1999; d'Acremont and Van der Linden, 2006; Rowe, Maughan, and Goodman, 2004), which can be defined as the set of beliefs about what it means to be a male or a female in terms of physical appearance, attitudes, interests, psychological traits, social relationships, and occupations (Ashmore, Del Boca, and Wohlers, 1986; Deaux and Lewis, 1984; Huston, 1983, 1985). Gender stereotypes are frequently studied as one of the more pervasive and accessible forms of categorical thinking (Brewer, 1988; Fiske and Neuberg, 1990) and the first of the three social categories (with race and age) to be acquired (Mackie, Hamilton, Susskind, and Rosselli, 1996).

In particular, gender stereotypes about risk-taking characterize it as a typically masculine type of behavior (Bem, 1981; Morrongiello and Hogg, 2004; Yagil, 1998). Research shows that gender stereotypes - through gender role conformity - have an effect on self-reported injury risk behavior in sports (Cazenave, Le Scanff, and Woodman, 2003), in driving behavior (Özkan and Lajunen, 2006; Sibley and Harré, 2009), in pedestrian behavior (Granié, 2009) and in general risk-taking among preschool children and adolescents (Granié, 2010; Raithel, 2003). Furthermore, gender stereotypes seem to be more predictive of risky behavior than biological sex (Granié, 2009, 2010; Raithel, 2003). The gender stereotype effect has also been studied for effective behavior on driving simulators (Schmid Mast, Sieverding, Esslen, 
Graber, and Jäncke, 2008). In all cases studied, research shows masculine stereotype conformity leads to more frequent injury risk behavior than feminine stereotype conformity. These studies are founded on hypotheses on the influence of gender roles and stereotypes on other neutral behavior, such as driving behavior. For instance, Simon and Corbet (1996) explain gender differences in driving as an expression of gender role differences, with the feminine role being passive, non-competitive and non-risky, while the masculine role is risky, competitive, aggressive and non-compliant. However, differentiated social expectations about driving behavior among men and women, that is stereotypes associated with women's and men's driving, are not been studied.

Berger (1986) tried to understand popular beliefs about driving among women and the development of a stereotype about how they drive. According to him, stereotype on female drivers is based on beliefs that women are unable to manage stressful situations requiring rapid decision-making, as is often the case in road situations. Research has studied accident risk perception according to the driver's gender (Glendon, Dorn, Davis, Matthews, and Taylor, 1996). Men are perceived as having a higher crash risks than women, whereas women are perceived as having poorer driving skills. This seems to suggest that accidents caused by women are more linked to an inability to adopt the right behavior (an act of omission), rather than a lack of caution (an act of commission) (Lawrence and Richardson, 2005). To the best of our knowledge, the content of this stereotype of women behind the wheel has not yet been explored in depth, neither among adults, nor among adolescents, although some research has tended to show that it is used by drivers (Davies and Patel, 2005; Derks, Scheepers, Laar, and Ellemers, 2011), and that it may have effects on driving behavior. Thus, one study showed that the threat of the stereotype of women behind the wheel - that is activating the stereotype that females are poor drivers - leads to a breakdown in driving performances in women driving on a simulator (Yeung and von Hippel, 2008). 
Driving gender stereotypes among French preadolescents and adolescents

The objective of this study is to determine the gender stereotypes associated with vehicle driving, i.e. to explore the role of the driver's gender on how his/her behavior is perceived. Further on, it is a question of exploring the effects of the perceiver's gender and his/her age on beliefs associated with the driver's gender.

It is interesting to observe whether there is a gender effect on the beliefs associated with men and women behind the wheel, according to an in-group serving bias (Glendon, et al., 1996). Gender being a category of affiliation for the subjects in the present study, we predict that the gender of the subjects questioned will have an effect on the characteristics attributed to drivers of both sexes, more particularly that the subjects will denigrate drivers in the outgroup more, attributing more negative characteristics to drivers of the opposite sex.

The objective of this research is also to find out how gender stereotypes associated with driving vary with age among adolescents, even before they begin driving. Research on the construction of gender identity shows that, very early on, children acquire knowledge of gender stereotypes by observing regular behaviors in their everyday social environment (family, peers, media) (Bussey and Bandura, 1999). In the driving field, children find themselves very early on in situations where they can observe adult drivers' behavior, notably as a passenger in the parental vehicle (Foot, et al., 2006; Granié, 2004). We can thus consider that these observable driving behaviors serve as a foundation for the early construction among children of beliefs on the typical behavior of men and women behind the wheel. As children's knowledge of gender stereotypes continues to increase in new domains after middle-school age (Martin, 1989) and gender-related beliefs become intensified during early adolescence (Berndt, 1996), we then hypothesize that typical behavior of driving men and women will be more and more differentiated with age. 
Thus, we propose the hypothesis that 1 / preadolescents and adolescents have beliefs about driver behavior that are differentiated according to the driver's gender, 2/ preadolescents and adolescents of the same gender group as the driver mentioned will attribute fewer negative characteristics to the driver than preadolescents and adolescents of the opposite sex and 3/ the characteristics associated with drivers of both sexes vary with the age of the preadolescents and adolescents questioned.

\section{Method, population and procedure}

\subsection{Information gathering method}

Measurements of beliefs about men's and women's driving behavior are relatively rare, as we have seen, and mostly American. Furthermore, this stereotype has not been measured in preadolescence and adolescence. It is therefore important, if we want to determine the content of the stereotype as it may exist in preadolescence and adolescence at the time of the study, to draw up an updated list of specific characteristics for the two populations studied (Devine and Elliott, 2000). We undertook to gather information using an open question on the characteristics that preadolescents and adolescents spontaneously associate with male and female drivers. This open question was inspired by the open-ended approach, which has been frequently used to measure stereotypes on social (Eagly, Mladinic, and Otto, 1991; Macrae, Bodenhausen, Milne, and Jetten, 1994) or ethnic groups (Bell, Esses, and Maio, 1996; Devine, 1989; Esses and Dovidio, 2002). The free association method consists in asking the individuals to indicate what comes into their minds when a given social group is mentioned (Devine, 1989; Ford and Stangor, 1992). This method is used to measure, as directly as possible, the strength of the association between a category label and the characteristics associated with it (Cantor and Mischel, 1979), but also to obtain a list of traits used to draw 
the current portrait of a group (Devine and Elliott, 2000). It is designed to evaluate the accessibility of a characteristic, in other words the chances of a characteristic's being activated when the category label of a group or one of its members is mentioned (Stangor and Lange, 1994). Under this approach, if one trait or one characteristic is stereotypical of a group, it must be strongly associated with this group in the individual's memory (Berjot and Drozda-Senkowska, 2007). The characteristics used to describe the group are thus freely chosen by the participants. Free association method enables us to obtain all the characteristics that come spontaneously to mind among French preadolescents and adolescents concerning men and women behind the wheel - but only these.

\subsection{Population and procedure}

An entire junior high school in south-eastern France participated to the study. The sample was made up of 599 preadolescents and adolescents from grades 7 to 10 (303 boys and 296 girls), between the ages of 10 and 16 years (mean $=12 \frac{1}{2}$ years), and divided into quartiles of age: 10-11 years, 12 years, 13 years and 14-16 years. Their parents were predominantly middlemanagement staff or white-collar workers (59\% of the fathers and $73 \%$ of the mothers).

The study was presented to the subjects as being carried out by researchers "who are interested in adolescents' representations of road users”. Students were equally divided by sex and age (table 1) and randomly distributed into two conditions: "traits associated with the female driver stereotype" versus "traits associated with the male driver stereotype". For the first condition (300 subjects, “female drivers" condition), the subjects were asked, "Concerning women drivers in general, what do people say, what do you hear, what do you imagine? Write down everything that comes to mind (words, phrases, expressions) and don't worry about making grammatical mistakes.” 
The second condition (299 subjects, "male drivers" condition) is expressed in the same way as the first, but on the subject of the other gender group: "Concerning men driving a car..." Two versions of these instructions were pretested to ensure that it was understandable for preadolescents and adolescents and produced the desired type of responses, i.e. general beliefs associated with the drivers of each sex, in all age groups. Thus, an oral version was pre-tested with children between the ages of 6 and 10, and a written format was pretested with 10-16 year old children and with adults.

After approval from the school inspectorate, the directors of the school, the teachers and the parents, the questionnaires were distributed to all the participants on the same day at the same time in a collective process in their respective classrooms with a teacher present. The participants provided consent to participate in the study and had 20 minutes to fill in the questionnaire. The questionnaires were anonymous and the participants were to indicate their gender, their age, their father and mother's professions and answer the question on drivers of one sex or the other.

\section{Results}

\subsection{Encoding the content}

The encoding’s construction follows the "grounded” approach Glaser and Strauss (1967). The study being exploratory by nature, its encoding was not developed before gathering the data but generated from data. This method, particularly widespread in qualitative data analysis, has already been used in research on gender identity (Ekins, 1993; Plummer, 2001) but not on gender stereotypes, to the best of our knowledge. This method of code generation has also been used before quantitative data analysis (Underwood, Dillon, Farnsworth, and Twiner, 2007). 
First encoder began with drawing up a list of all the spontaneous answers and their semantic consolidation for each target separately. This preliminary encoding was then used to categorize the answers (Glaser and Strauss, 1967; Miles and Huberman, 1994) and create for each target open and descriptive sub-categories - or characteristics, for example "aggressive”, “good driving” -, categories - for example “careless driver”, "good driver” -, and general topics - for example "safety" or "driving quality" -, on which both encoders agreed. As in other studies (Esses and Dovidio, 2002; Underwood, et al., 2007), once all the data were encoded by the first encoder using this categorization, the second encoder encoded a sub-body of data (8\% of the sampling) using the same characteristics and topics developed with the primary encoders, with a good interrater reliability (100\%).

For each preadolescent and adolescent questioned, all the answers produced were coded according to the characteristics constructed in the content analysis and as a function of the gender of the driver being referred to. Presence of each characteristic is counted just once in each discourse, even if it appears more than once. The discourses of the 599 participants produced 2345 analyzed characteristics for an average of 3.91 different characteristics per individual. The analysis of the thematic content, performed on the body of data, shed light on all the characteristics mentioned in each of the conditions.

\subsection{Analysis of thematic content}

The objective of the article being to analyze the characteristics associated with each gender, in the following analyses we will only keep those characteristics whose frequency of appearance is greater than or equal to .08 for at least one of the two targets (Berjot and DrozdaSenkowska, 2007). As a reminder, these characteristics are the product of the semantic consolidation of spontaneous answers from the participants. 
It should be pointed out that preadolescents and adolescents often refer to men behind the wheel when they are asked about women, whereas participants questioned about men behind the wheel rarely refer to women. Thus, two characteristics of men behind the wheel have an average frequency of appearance that is greater than .08 in the group questioned about women: the "is dangerous" characteristic (.09) and the "positive relation between driving and masculinity” characteristic (.11). No characteristic describing women behind the wheel reached an average frequency of appearance that is greater than .08 among the participants questioned about men behind the wheel.

For the following analysis, however, we will only use those characteristics associated with the target that the participants were questioned about: 1/ characteristics associated with male drivers for the "traits associated with stereotypes of men behind the wheel" group and 2/ characteristics associated with female drivers for the "traits associated with the stereotypes of women behind the wheel” group.

Characteristics coded were used to define topics in the discourses on male's and female's targets separately. However, the same 4 topics have been found in discourses on male and female drivers.

The first topic concerns characteristics in relation to general driving quality (good / bad driver, driving capacities, etc.). The second topic referred to driving behavior in relation to safety (safe, unsafe, frequency of accidents, dangerous driving, related behavior behind the wheel, etc.). The third topic concerns driving behavior in relation to the rules (Highway Code, speed, use of psychotropic drugs, respect for others). Lastly, the fourth topic consolidates content that mentions the relationship between driving and the driver's gender group, notably in terms of social identity (masculine / feminine roles, attraction for driving and vehicles, promoting oneself through driving). It should be pointed out that, throughout the body of data, 
there is a very high frequency of explicit comparisons with the other gender group (more/less than...), whatever the target's gender.

The topics were thus systematically dichotomized for the valence of the characteristics indicated: strong-weak, good-bad, etc. We obtained, for male’s target as for female's target, the same 8 categories of discourse grouping together the different positive and negative characteristics used by the preadolescents and adolescents to describe men and women behind the wheel: good driver, bad driver, careful driver, careless driver, compliant driver, offending driver, identity consistency, identity discrepancy. The distribution of the spontaneous answers from the participants into different characteristics, categories and topics set up after the analysis of the content is presented in the appendix.

3.3. Distribution of topics, categories and characteristics describing men and women behind the wheel

Topics and categories appear to be the same in discourses on both targets. However, a first analysis of the distribution of occurrences in each category and for each of the two target groups (male drivers and female drivers) indicates that the topics and the categories are not distributed equally for the two targets (table 2).

Concerning male drivers, the participants' discourses produced 1214 occurrences for an average of 4.06 characteristics cited per individual. Predominant topics are male drivers' behaviors in relation to safety (37\%), and in relation to the rules (36\%). Male drivers are especially defined by their traffic offenses (35 \%) and their carelessness (34\%) and, to a lower level, by the identity consistency between driving and masculine role (12\%). Some characteristics frequently appear in discourses on male drivers (table 3): drives at high speed (mean frequency of appearance: 0.55), aggressive driver (0.42), does not comply with traffic rules (0.39), careless driver (0.29) and drives under influence (0.25). 
Concerning female drivers, the participants' discourses produced 1131 occurrences for an average of 3.77 characteristics cited per individual. Discourses on female drivers insist on their behaviors in relation to safety (43\%) and in relation to the rules (27\%). Female drivers are mainly defined by their carelessness (26\%), their compliance with traffic rules (18\%), their carefulness $(17 \%)$ and the poor quality of their driving (16\%). Some characteristics frequently appear in discourses on female drivers (table 3): careful driver (mean frequency of appearance: 0.40$)$, bad driver (0.39), drives at low speed (0.33) and has a lot of accidents (0.28).

\subsection{Effect of target on frequency of appearance of categories and characteristics}

Mean difference comparison was performed on independent samples using Student's t to study the effect of the target on the mean frequency of appearance of each topical category. The mean frequencies for each target and each category are summed up in table 3.

The mean frequencies comparisons show significant differences between the "male drivers" and “female drivers" targets for all categories.

Several categories appear more frequently for male drivers than for female drivers: categories concerning good driving quality $(\mathrm{t}(597)=2.06, \mathrm{p}<.05)$, careless driving $(\mathrm{t}(597)=3.38, \mathrm{p}<$ $.01)$, offending driving $(\mathrm{t}(597)=10,62, \mathrm{p}<.001)$ and identity consistency $(\mathrm{t}(597)=5,57, \mathrm{p}<$ $.001)$

Other categories are more frequently used to describe female drivers: categories concerning bad driving quality $(\mathrm{t}(597)=-8.59, \mathrm{p}<.001)$, careful driving $(\mathrm{t}(597)=-8.57, \mathrm{p}<.001)$, compliant driving $(\mathrm{t}(597)=-10.18, \mathrm{p}<.001)$ and identity discrepancy $(\mathrm{t}(597)=-5.55, \mathrm{p}<$ $.001)$.

Mean difference comparison was performed on independent samples using Student's t to study the effect of the target on the mean frequency of appearance of each characteristic used 
in the analysis. The mean frequencies, the $t$ values and their significance are summed up in table 4. The mean frequencies comparisons show significant differences between the "male drivers" and "female drivers” targets for all characteristics, except for the "is dangerous" and “is not concentrated on driving” characteristics.

Statistically, the mean frequencies of appearance are significantly higher for the "male drivers" target than for the "female drivers" target for the following characteristics. Male drivers are more frequently perceived than female drivers as being good drivers, not being concentrated on the driving task, aggressive, not complying with traffic rules, driving too fast, frequently consuming psychotropic drugs before driving, enjoying driving and cars, and using their vehicle to promote their image of themselves.

Statistically, the mean frequencies of appearance are significantly higher for the "female drivers" target than for the "male drivers" target for the following characteristics. Female drivers are more frequently perceived than male drivers as being bad drivers, concentrating on the driving task, having few accidents, having a lot of accidents, complying with traffic rules, controlling their speed and their consumption of alcohol and drugs, being engaged in an activity that is not feminine, having behaviors that are not very different from men's.

\subsection{Effects of the perceiver's gender and age on the image associated with each target}

\subsubsection{Gender and age differences for categories associated with male drivers}

Mean difference testing using ANOVA was performed on the effect of gender (2) and age (4) on the mean frequencies of appearance of each category of characteristics associated with male drivers. The mean frequencies of each category for each gender group and each age group are summed up in table 5 . 
Describing the male drivers, there were significant main effects of perceiver's gender on mean frequency of appearance of some categories. Categories of "careless" $(F(1,291)=7.72$, $\mathrm{p}<.01)$, “offending driving” $(\mathrm{F}(1,291)=4.58, \mathrm{p}<.05)$, “identity consistency” $(\mathrm{F}(1,291)=$ 5.21, $\mathrm{p}<.05)$ and "identity discrepancy" $(\mathrm{F}(1,291)=4.08, \mathrm{p}<.05)$ appear more frequently among girls than among boys.

There was no significant main effect of perceiver's age on categories associated to male drivers. Nevertheless, there was a significant interaction between perceiver's age and perceiver's gender on the frequency of appearance of the "offending driving” category $(\mathrm{F}(3,291)=3.73, \mathrm{p}<.05)$. While this category is more common among girls at 12 years (1.74) and 13 years (1.52) than among 10-11 year-olds (.95) and 14-16 year-olds (1.18), it appears less frequently among boys at 12 years (.89) and 13 years (.72) than at 10-11 years (1.12) and 14-16 years (1.37). No other differences as function of age were observed for the other categories.

\subsubsection{Gender and age differences on categories associated with female drivers}

Mean difference testing using ANOVA was performed on the effect of gender (2) and age (4) on the mean frequencies of appearance of each category of characteristics associated with female drivers. The mean frequencies of each category for each gender group and each age group are summed up in table 6.

Describing the female drivers, there was a significant main effect of perceiver's gender on mean frequency of appearance of one category. The "careful" category appears more frequently among girls than among boys $(\mathrm{F}(1,292)=8.52, \mathrm{p}<.01)$.

We observe significant mean effects of perceiver's age on frequency of appearance of three categories: "bad drivers" $(\mathrm{F}(3,292)=5.31, \mathrm{p}<.01)$, "careful” $(\mathrm{F}(3,292)=4.66, \mathrm{p}<.01)$ and 
Driving gender stereotypes among French preadolescents and adolescents

"careless" $(\mathrm{F}(3,292)=3.45, \mathrm{p}<.05)$. The Bonferroni post hoc tests show significant differences at .05 for these three categories: 14-16 year-old adolescents use these categories more frequently than all other age groups for the "bad drivers" category, than 10-11 year-olds for the "careful” category, than 10-11 year-olds and 12 year-olds for the “careless” category. Furthermore, there was a significant interaction between perceiver's age and perceiver's gender on the frequency of appearance of the "identity discrepancy" category $(F(3,292)=$ 4.22, $\mathrm{p}<.01$ ). This category is as common among boys as among girls at the age of $10-11$ (.18 and .20, respectively). At 12 , however, this category is more frequent among girls (.42) than among boys (.03), whereas at 13 years and 14-16 years, boys use this category more than girls (.31 and .39 for boys, .19 and .28 for girls at 13 years and 14-16 years, respectively).No other differences as function of age or gender were observed for the other categories mentioned.

\section{Discussion}

The objective of this study was to determine which gender stereotypes are associated with driving a vehicle. Further on, it was a question of exploring the differences related to the perceiver's gender and age on the gender stereotypes associated with driving. While largely descriptive, the interest of this study was first to try and make up for a lack by obtaining an updated national representation of drivers according to gender. Not only because drivers represent the principal population in research on traffic psychology, but also because research is increasingly interested in the influence of gender stereotype conformity on driving behavior (Özkan and Lajunen, 2006; Schmid Mast, et al., 2008; Sibley and Harré, 2009; Yeung and von Hippel, 2008), whereas gender stereotypes associated with driving have, to the best of our knowledge, only rarely been studied. 
The results, only based on characteristics associated with the target that the participants were questioned about, show that the characteristics attributed to a driver by the participants questioned vary significantly as a function of the driver's gender. Our first hypothesis, which predicted that preadolescents and adolescents had beliefs about driver behaviors differentiated according to the driver's gender, was confirmed. Concerning the representation of male drivers, the data obtained from the participants questioned give a picture of a driver who is judged good, skilled, involved in an activity that complies with social expectations, while being careless and committing driving offenses. Concerning female drivers, the results show that they are perceived as being careful drivers who comply with the rules and have few accidents, while being unskilled, having a lot of accidents and being involved in an activity that does not correspond to social expectations concerning their gender group. The principal characteristics are in line with the stereotypes that present men as being more aggressive and risk-takers (Locksley, Borbiga, Brekke, and Hepburn, 1980), more skilled (DeJoy, 1992; Rothe, 1987; K. Stoddart, 1987) and women as being less active and more hesitant (Harris and Miller, 2000), having fewer accidents, but also as having weaker driving skills (Glendon, et al., 1996).

\subsection{Driving and gender roles}

From a theoretical point of view, these results show that, already in pre-adolescence and adolescence, gender stereotypes are at work in the driving context. The results show that women are perceived as drivers with high accident rates, which appears to be related to their poor vehicle control and the mismatch between the driving activity and the feminine role in society. Lawrence and Richardson (2005) thus pointed out that women's accidents were attributed by adult subjects to an uncontrollable internal cause, defined by Shaver (1985) as acts of omission, the consequences of which are not foreseen or intentional. 
Men are perceived as drivers who are skilled while being careless and committing offenses. In our results, this good driving quality goes hand-in-hand with the good match between the driving activity and the masculine role in society. This representation reflects the ideas in Western societies that driving skills are an integral part of what it means to be a man (Harré, et al., 1996). This also suggests that accidents caused by male drivers tend to be judged in terms of carelessness or risk-taking, i.e. acts of commission whose negative consequences are known but not taken into account (Lawrence and Richardson, 2005).

These gender stereotypes could seem contradictory, as female drivers are seen as unskilled whereas they are seen as driving safer, paying more attention, having less accidents and complying more with traffic rules. These results could be understood when reported to previous research differentiates driving and safety skills (Lajunen and Summala, 1995). The former is based on information processing and motor skills (Näätänen and Summala, 1976) and determines driving performances in different driving tasks (maneuver or hazard detection). The second is based on motivational and personality factors and attitudes toward traffic and safety (Näätänen and Summala, 1976) and determines driving style, i.e. ways drivers choose to drive or habitually drive (driving speed or attentiveness)(Sundström, 2008). In our results, it seems pre-adolescents' and adolescents' perceptions of drivers differentiate driving skills and safety skills. Female are seen as unskilled but safe drivers, whereas male are seen as skilled but unsafe drivers.

Thus, including driving among the male gender roles appears to determine, in the content analyzed, the ability to drive of individual of either sex in an essentialist view of gender roles (Heyman and Giles, 2006; Prentice and Miller, 2006; Tostain and Lebreuilly, 2005). From this viewpoint, an individual's qualities and skills are perceived as inherent to his/her category of affiliation, rather than constructed in a social group (Bohan, 1993). It has been demonstrated, for example, that parents believe boys are naturally risk takers (Morrongiello 
and Dayler, 1996). Furthermore, the essence of the category not only determines what its members are, but also what they can become, notably their skills (Prentice and Miller, 2006). Thus, preadolescents and adolescents seem to consider that being a man entails naturally driving skills. On the other hand, they seem to feel that women are naturally unfit for driving. Furthermore, in our results this essentialist perception of driving skills seems to be negatively linked with perception of safety skills. It seems that male natural driving skills allow male drivers to take risks, in particular by offending driving, whereas female natural poor driving skills lead female drivers to be careful and compliant. This can be compared with the results of Näätänen and Summala (1976), which showed that the propensity to drive fast and to overtake other vehicles was generally considered as proof of skill.

\subsection{In-group / out-group relations}

The results also show differences depending on the perceiver's gender and age concerning characteristics associated with drivers of each sex. The results show that girls, more than boys, perceive male drivers as careless, committing offenses and using driving to promote themselves. Boys do not attribute more negative characteristics than girls to female drivers. Our second hypothesis, which stipulates that preadolescents and adolescents in the same gender group as the driver mentioned will attribute fewer negative characteristics to this driver than those of the opposite sex was only confirmed on the representation of male drivers. Thus, boys attribute fewer negative characteristics to male drivers than girls, but girls do not attribute fewer negative characteristics to female drivers than boys. Furthermore, girls, more than boys, perceive female drivers as careful, whereas boys do not attribute more positive characteristics to male drivers. Thus, girls denigrate drivers from the out-group more than boys, by attributing to them more negative characteristics. On the other side girls 
promote drivers from the in-group more than boys, by attributing to them more positive characteristics.

These two results are in keeping with research on gender stereotypes and, more generally on intergroup relations, which have shown how individuals seek positive distinctiveness, by denigrating the out-group while promoting the in-group (Allen and Wilder, 1975; Brewer and Silver, 1978; Tajfel and Turner, 1986). Power-based gender stereotype approaches (Zemore, Fiske, and Kim, 2000) and the effects of social asymmetry between the sexes (Hurtig, Kail, and Rouch, 2002) can provide an understanding of these results among girls. Thus, research has shown that the dominant position of the male group (Lorenzi-Cioldi, 1988a, 1988b; Sidanius, Pratto, and Rabinowitz, 1994) leads members of the socially dominated female group to over-promote the in-group (Powlishta, 1995; Rudman and Goodwin, 2004; Serbin, Powlishta, and Gulko, 1993). It appears that associating the driving activity with the male role in society causes girls to "defend" their gender identity more than boys need to.

\subsection{Age difference in stereotypes and identity construction}

An observation of the effects of age raises several questions. First of all, age appears to have less of an effect on the image of male drivers than on the image of female drivers. Indeed, no category concerning male drivers varies in frequency as a function of age. The image of men behind the wheel appears relatively stable throughout the age groups, and already seems to be relatively constructed by the age of 10-11 years. For female drivers, two negative categories (bad driving, carelessness) and one positive category (carefulness) are mentioned with increasing frequency as adolescents grow older. Thus, our third hypothesis, which predicted that the characteristics associated with drivers of either sex vary with the age of the preadolescents and adolescents questioned, is only partially confirmed: gender stereotypes associated with female drivers are reinforced with age, whereas gender stereotypes associated 
with male drivers do not seem to vary during adolescence. This increase with age in the characteristics - notably negative ones - associated with female drivers can be compared with the results in the literature. It has been demonstrated among children between the ages of 3 and 11 years that the more negative judgments concerning counter-stereotyping are related to the appearance for boys (i.e. boy with feminine appearance) and to the activity for girls (girl engaged in masculine activity) (Owen Blakemore, 2003), and these negative judgments increase between childhood and adolescence (T. Stoddart and Turiel, 1985). Thus, the increase with age in the negative image of women behind the wheel obtained in our results might be explained by the general increase in negative judgments about women involved in activities considered as being typically masculine, here, driving a vehicle.

We can also observe interactions between gender and age for both targets. These interaction effects are in keeping with a differentiation between boys and girls at age 12. This is the age, more than other ages, at which girls insist on men's offending driving, and on identity discrepancy - notably the absence of differences between men and women - concerning women drivers, and it is also the age at which boys insist the least on these same points. These results could be an effect of search for positive distinctiveness and of gender intensification (Hill and Lynch, 1983) at age 12, as research shows gender stereotype conformity tends to peak of in the early adolescent period and then decline over time (Berndt, 1996). Furthermore, research shows that girls increase their approval of gender equality and role flexibility across middle school, whereas boys actually become more traditional (Galambos, Almeida, and Petersen, 1990) and that girls approve of equality between men and women more than do boys, especially between the ages of 11 and 13 (Canter and Ageton, 1984). Thus, differentiation of attitudes toward gender roles, gender intensification, and positive distinctiveness in early adolescent period could explain why gap between boys and girls in perceptions of male and female drivers widened at age 12 . 


\subsection{Practical consequences on driver's training and socialization to risk-taking}

On a practical level, the results of this study could be linked to gender differences that seem to emerge during driver's training. Research has shown that boys in training feel that they are more competent than the girls, and that girls appear to plan their training in a more structured manner (Nyberg and Gregersen, 2007), preparing more for the theoretical test than boys because they are involved in a "traditionally masculine" activity that is less familiar to them (Wiberg, 2006). Girls' and boys' attitudes toward training could be an effect of stereotypical representations, which are apparently already constructed at the beginning of adolescence, of males as naturally skilled and of females as naturally unskilled drivers.

We might also ask how these stereotypes influence the behavior of educators (parents and teachers) toward both sexes during driver's training and earlier. The results of research on parental practices show how the representations of both sexes in terms of risk-taking affect educational practices from early childhood, with parents, especially fathers (Hagan and Kuebli, 2007), seeking to educate girls to avoid risk while not seeking to avoid, or even encouraging, the risk-taking considered as innate in boys (Morrongiello and Dawber, 1999; Morrongiello and Dayler, 1996). Among drivers, studies have already demonstrated the influence of the parental driving style on the child's behavior once he/she starts driving, notably with a transmission of driving style between parent and child of the same sex (Taubman - Ben-Ari, Mikulincer, and Gillath, 2005).

\section{Conclusions}

This research has tried to differentiate the images of men and women behind the wheel among preadolescents and adolescents in terms of differences in the frequency of appearance of the same characteristics for the two groups of drivers. These results are based on the accessibility 
of traits and characteristics in the memory. They give insight into the content of stereotypes, but they do not yet make it possible to draw any conclusions as to the strength of the stereotypes by determining the distinctive traits that are most strongly associated with each category. This would be possible using methods based on the availability of traits within representations, such as the diagnostic report (McCauley and Stitt, 1978).

These results can, however, be used as a basis for more detailed research on the makeup of these stereotypes, on the effect of taking stereotypes into account in individuals' driving behavior and on socialization to risk-taking which may be based on these.

The results show that gender stereotypes associated with driving do indeed exist and can be detected in individuals' discourses from the earlier period of adolescence. These gender stereotypes associated with driving are the expression of more general gender stereotypes: female compliance and male risk-taking. Furthermore, they expose an essentialist view of gender roles. Thus, the social promotion of an activity for a certain group of individuals, here men, lead preadolescents and adolescents to interpret the underlying abilities as naturally present in the individuals of this group and to consider individuals of the other group as being naturally unfit. These beliefs might explain why the threat of stereotype of female driver that is activating the stereotype that females are poor drivers - can lead to an impairment of driving performances among women, as measured on a simulator (Yeung and von Hippel, 2008). These results show a tendency among preadolescents and adolescents to assimilate information and activities related to driving a vehicle with existing gender stereotypes, but also to accommodate their incomplete representations of gender groups for new information concerning this activity (Prentice and Miller, 2006).

The results from Mann and Lansdown (2009) show that boys in the 12-16 age group have more risky attitudes than girls of the same age in terms of speed and not wearing a seatbelt, even before they start driving, confirming the results by Harré, Field and Kirkwood (1996) on 
15-year-old adolescents. These results could thus be explained by the boys' acceptance of and compliance with the image they have constructed about male drivers. Lastly, the results of this study show that, beyond driving behavior itself, the representation of male and female drivers appears to be a field of expression of personal and social identity (Green, 1997; Green and Hart, 1998; Papadakis and Moore, 1991; Walker, Butland, and Connell, 2000) in a culture where seeking out risk is part of the manliness construction (Hopkins and Emler, 1990).

\section{References}

Aberg, L., and Rimmö, P.-A. (1998). Dimensions of aberrant driver behaviour. Ergonomics, 41, 39-56.

Allen, V. L., and Wilder, D. A. (1975). Categorization, belief similarity, and group discrimination. Journal of Personality and Social Psychology, 31, 971-977.

Ashmore, R. D., Del Boca, F. K., and Wohlers, A. J. (1986). Gender stereotypes. In R. D. Ashmore and F. K. Del Boca (Eds.), The social psychology of female-male relations : a critical analysis of central concepts (pp. 69-119). New York: Academic Press.

Assailly, J.-P. (2001). La mortalité chez les jeunes [Teenagers' mortality]. Paris: Que sais-je? P.U.F.

Bell, D. W., Esses, V. M., and Maio, G. R. (1996). The utillity of open-ended measures to assess intergroup ambivalence. Canadian Journal of Behavior Science, 28, 12-18.

Bem, S. L. (1981). Gender schema theory: a cognitive account of sex-typing. Psychological Review, 88, 354-364.

Bergdahl, J. (2007). Ethnic and gender differences in attitudes toward driving. The Social Science Journal, 44, 91-97.

Berger, M., L. (1986). Women drivers!: the emergence of folklore and stereotypic opinions concerning feminine automotive behavior. Women's Studies International Forum, 9, 257-263. 
Berjot, S., and Drozda-Senkowska, E. (2007). Comment les étudiants se perçoivent-ils en fonction de leur origine sociale ? Étude de contenu du stéréotype [How students from different socio-economic status perceive themselves? Study of the SES stereotype content]. Revue Européenne de Psychologie Appliquée [European Review of Applied Psychology], 57, 119-132.

Berndt, T. J. (1996). Transitions in friendship and friends' influence. In J. A. Graber, J. Brooks-Gunn and A. C. Petersen (Eds.), Transitions through adolescence: Interpersonal domains and context (pp. 57-84). Mahwah, NJ: Erlbaum.

Bina, M., Graziano, F., and Bonino, S. (2006). Risky driving and lifestyles in adolescence. Accident Analysis and Prevention, 38 472-481.

Blockey, P. N., and Hartley, L. R. (1995). Aberrant driving behaviour: errors and violations. Ergonomics, 38, 1759-1771.

Bohan, J. S. (1993). Essentialism, Constructionism, and Feminist Psychology. Psychology of Women Quarterly, 17, 5-21.

Brewer, M. B. (1988). A dual-process model of impression formation. In T. K. Srull and R. S. Wyer (Eds.), Advances in social cognition (Vol. 1, pp. 1-36). Hillsdale, NJ: Lawrence Erlbaum.

Brewer, M. B., and Silver, M. (1978). Ingroup bias as a function of task characteristics. European Journal of Social Psychology, 8, 393-400.

Bussey, K., and Bandura, A. (1999). Social Cognitive Theory of Gender Development and Differentiation. Psychological Review, 106, 676-713.

Byrnes, J. P., Miller, D. C., and Schafer, W. D. (1999). Gender differences in risk taking: a meta-analysis. Psychological Bulletin, 125, 367-383.

Canter, R. J., and Ageton, S. S. (1984). The epidemiology of adolescent sex-role attitudes. Sex Roles, 11, 657-676.

Cantor, N., and Mischel, W. (1979). Prototypicality and personality: Effects on free recall and personality impressions. Journal in Research in Personality, 13, 187-205. 
Cazenave, N., Le Scanff, C., and Woodman, T. (2003). Spécificité de la prise de risque chez les femmes [Specificity of risk-taking among women]. In 10e Congrès de l'Association des Chercheurs en Activités Physiques et Sportives (ACAPS). Toulouse.

d'Acremont, M., and Van der Linden, M. (2006). Gender differences in two decision-making tasks in a community sample of adolescents. International Journal of Behavioral Development, 30, 352-358.

Daly, M., and Wilson, M. (1987). Evolutionary psychology and family violence. In C. Crawford, M. Smith and D. Krebs (Eds.), Sociobiology and Psychology: ideas issues and applications (pp. 293-309). Hillsdale, NJ: Erlbaum.

Davies, G. M., and Patel, D. (2005). The influence of car and driver stereotypes on attributions of vehicle speed, position on the road and culpability in a road accident scenario. Legal and Criminological Psychology, 10, 45-62.

Deaux, K., and Lewis, L. L. (1984). Structure of gender stereotypes : interrelations among components and gender labels. Journal of Personality and Social Psychology, 46, 991-1004.

DeJoy, D. M. (1992). An examination of gender differences in traffic accident risk perception. Accident Analysis and Prevention, 24, 237-246.

Derks, B., Scheepers, D., Laar, C. V., and Ellemers, N. (2011). The threat vs. challenge of car parking for women: How self- and group affirmation affect cardiovascular responses. Journal of Experimental Social Psychology, 47 178-183.

Devine, P. G. (1989). Stereotypes and prejudice: Their automatic and controlled components. Journal of Personality and Social Psychology, 56, 5-18.

Devine, P. G., and Elliott, M. A. (2000). Are racial stereotypes really fading? The Princeton trilogy revisited. In S. Stangor (Ed.), Stereotypes and prejudice (Vol. Reading 4, pp. 86-99). Philadelphia: Francis and Taylor.

Doherty, S. T., Andrey, J. C., and MacGregor, C. (1998). The situational risks of young drivers: the influence of passengers, time of day, and day of week of accident rates. Accident Analysis and Prevention, 30, 45-52. 
Eagly, A. H., Mladinic, A., and Otto, S. (1991). Are Women Evaluated More Favorably Than Men? An Analysis of Attitudes, Beliefs, and Emotions. Psychology of Women Quarterly, 15, 203-216.

Ekins, R. (1993). On male femaling: a grounded theory approach to cross-dressing and sexchanging. Sociological Review, 41, 1-29.

Esses, V. M., and Dovidio, J. F. (2002). The Role of Emotions in Determining Willingness to Engage in Intergroup Contact. Personality and Social Psychology Bulletin, 28 1202-1214.

Farrow, J. A., and Brissing, P. (1990). Risk for DWI: A New Look at Gender Differences in Drinking and Driving Influences, Experiences, and Attitudes among New Adolescent Drivers. Health Education and Behavior, 17, 213-221.

Fiske, S. T., and Neuberg, S. L. (1990). A continuum model of impression formation from category-based to individuating response: Influences of information and motivation on attention and interpretation. In M. P. Zanna (Ed.), Advances in experimental social psychology (Vol. 23, pp. 1-108). New-York, NY: Academic Press.

Foot, H. C., Thomson, J. A., Tolmie, A. K., Whelan, K., Morrison, S., and Sarvary, P. (2006). Children's understanding of drivers' intentions. British Journal of Developmental Psychology, 24, 681-700.

Ford, T. E., and Stangor, C. (1992). The role of diagnosticity in stereotype formation: perceiving group means and variances. Journal of Personality and Social Psychology, 63, 356-367.

Galambos, N. L., Almeida, D. M., and Petersen, A. C. (1990). Masculinity, femininity and sex role attitudes in early adolescence: exploring gender intensification. Child Development, 61, 1905-1914.

Glaser, B. G., and Strauss, A. L. (1967). The discovery of grounded theory: strategies for qualitative research. Chicago: Aldine.

Glendon, A. I., Dorn, L., Davis, R., Matthews, G., and Taylor, R. G. (1996). Age and gender differences in perceived accident likelihood and driver competences. Risk Analysis, 16. 
Granié, M.-A. (2004). La construction des règles comportementales sur le port de la ceinture chez l'enfant: analyse du contenu d'entretiens auprès d'enfants de 5 et 8 ans [Children's construction of behavioral rules for seat-belt use. Content analysis of interviews with five and eight year-old children]. Recherche - Transports - Sécurité, 83, 99-114.

Granié, M.-A. (2009). Sex differences, effects of sex-stereotype conformity, age and internalization on risk-taking among pedestrian adolescents. Safety Science, 47, 1277-1283.

Granié, M.-A. (2010). Gender stereotype conformity and age as determinants of preschoolers' injury-risk behaviors. Accident Analysis and Prevention, 42, 726-733.

Green, J. (1997). Risk and the construction of social identity: children's talk about accidents. Sociology of Health and Illness, 19, 457-479.

Green, J., and Hart, L. (1998). Children's views of accident risks and prevention: a qualitative study. Injury Prevention, 4, 14-21.

Hagan, L. K., and Kuebli, J. (2007). Mothers' and fathers' socialization of preschoolers' physical risk taking. Journal of Applied Developmental Psychology, 28, 2-14.

Hanna, C. L., Taylor, D. M., Sheppard, M. A., and Laflamme, L. (2006). Fatal crashes involving young unlicensed drivers in the US. Journal of Safety Research, 37, 385-393.

Harré, N., Brandt, T., and Dawe, M. (2000). The Development of Risky Driving in Adolescence. Journal of Safety Research, 31, 185-194.

Harré, N., Field, J., and Kirkwood, B. (1996). Gender differences and areas of common concern in the driving behaviors and attitudes of adolescents. Journal of Safety Research, 27, 163-173.

Harris, M. B., and Miller, K. C. (2000). Gender and perception of gender. Sex Roles, 43, 843863.

Heyman, G. D., and Giles, J. W. (2006). Gender and Psychological Essentialism. Enfance, 3, 293-310. 
Hill, J. P., and Lynch, M. E. (1983). The intensification of gender-related role expectations during early adolescence. In J. Brooks-Gunn and A. C. Petersen (Eds.), Girls at puberty: Biological and psychosocial perspectives (pp. 201-228). New-York, NY: Plenum.

Hopkins, N., and Emler, N. (1990). Social network participation and problem behavior in adolescence. In K. Hurrelman and F. Lösel (Eds.), Health hazards in adolescence (pp. 385407). Berlin: de Gruyter.

Hurtig, M. C., Kail, M., and Rouch, H. (2002). Sexe et genre. De la hiérarchie entre les sexes [Sex and Gender. On hierarchy between genders]. Paris: CNRS.

Huston, A. (1983). Sex-typing. In E. M. Hetherington (Ed.), Handbook of Child Psychology. Vol. IV Socialization Personality and social development (Vol. Vol. IV Socialization Personality and social development, pp. 387-468). New-York: Wiley.

Huston, A. (1985). The development of sex-typing: themes from recent research. Developmental Review, 5, 1-17.

Lajunen, T., and Summala, H. (1995). Driver experience, personality, and skill and safety motive dimensions in drivers' self-assessments. Personality and Individual Differences, 19, 307-318.

Lawrence, C., and Richardson, J. (2005). Gender-based judgements of traffic violations: the moderating influence of car type. Journal of Applied Social Psychology, 35, 1755-1774.

Lin, M.-L., and Fearn, K. T. (2003). The provisional license: nighttime and passenger restrictions -- a literature review. Journal of Safety Research, 34, 51-61.

Locksley, A., Borbiga, E., Brekke, N., and Hepburn, C. (1980). Sex stereotypes and social judgement. Journal of Personality and Social Psychology, 39, 821-831.

Lonczak, H. S., Neighbors, C., and Donovan, D. M. (2007). Predicting risky and angry driving as a function of gender. Accident Analysis and Prevention, 39, 536-545.

Lorenzi-Cioldi, F. (1988a). Discriminations entre soi et autrui et catégorisation sociale. Revue Internationale de Psychologie Sociale, 1, (2), 239-256. 
Lorenzi-Cioldi, F. (1988b). Individus dominants et groupes dominés [Dominant individuals and dominated groups]. Grenoble: Presses Universitaires de Grenoble.

Mackie, D. M., Hamilton, D. L., Susskind, J., and Rosselli, F. (1996). Social psychological foundations of stereotype formation. In C. N. Macrae, C. Stangor and M. Hewstone (Eds.), Stereotypes and stereotyping (pp. 41-78). New-York: Guilford.

Macrae, C. N., Bodenhausen, G. V., Milne, A. B., and Jetten, J. (1994). Out of Mind but Back in Sight: Stereotypes on the Rebound Journal of Personality and Social Psychology, 67, 808817.

Mann, H. N., and Lansdown, T. (2009). Pre-driving adolescent attitudes: Can they change? Transportation Research Part F: Traffic Psychology and Behaviour, 12, 395-403.

Martin, C. L. (1989). Children's use of gender-related information in making social judgments. Developmental Psychology, 25, 80-88.

McCauley, C., and Stitt, C. L. (1978). An individual and quantitative measure of stereotypes. Journal of Personality and Social Psychology, 36, 929-940.

Miles, M. B., and Huberman, A. M. (1994). An expanded sourcebook. Qualitative data analysis. London: Sage.

Morrongiello, B. A., and Dawber, T. (1999). Parental influences on toddlers' injury-risk behaviors: are sons and daughters socialized differently? Journal of Applied Developmental Psychology, 20, 227-251.

Morrongiello, B. A., and Dayler, L. (1996). A community-based study of parents' knowledge, attitudes and beliefs related to childhood injuries. Canadian Journal of Public Health, 87, 383388.

Morrongiello, B. A., and Hogg, K. (2004). Mother's reactions to children misbehaving in ways that can lead to injury: implications for gender differences in children risk taking and injuries. Sex Roles, 50, 103-118.

Näätänen, R., and Summala, H. (1976). Road User Behavior and Traffic Accidents. Amsterdam/New York: North-Holland/American Elsevier. 
Nell, V. (2002). Why young men drive dangerously: implications for injury prevention. Current Directions in Psychological Science, 11, 75-79.

Nyberg, A., and Gregersen, N. P. (2007). Practicing for and performance on drivers license tests in relation to gender differences in crash involvement among novice drivers. Journal of Safety Research, 38, 71-80.

Owen Blakemore, J. E. (2003). Children's beliefs about violating gender norms: boys shouldn't look like girls, and girls shouldn't act like boys. Sex Roles, 48, 411-419.

Özkan, T., and Lajunen, T. (2005). Why are there sex differences in risky driving? The relationship between sex and gender-role on aggressive driving, traffic offences, and accident involvement among young turkish drivers. Aggresive Behavior, 31, 547-558.

Özkan, T., and Lajunen, T. (2006). What causes the differences in driving between young men and women? The effects of gender roles and sex on young drivers' driving behaviour and self-assessment of skills. Transportation Research Part F: Traffic Psychology and Behaviour, 9, 269-277.

Papadakis, E., and Moore, A. (1991). Drink-driving and adolescent lifestyles: Rethinking policy. Australian Journal of Social Issues, 25, 83-106.

Plummer, D. C. (2001). The quest for modern manhood: masculine stereotypes, peer culture and the social significance of homophobia. Journal of Adolescence, 24, 15-23.

Powlishta, K. K. (1995). Intergroup processes in childhood: Social categorization and sex role development. Developmental Psychology, 31, 781-788.

Prentice, D. A., and Miller, D. T. (2006). Essentializing Differences Between Women and Men. Psychological Science, 17, 129-135.

Preusser, D., Ferguson, S., and Williams, A. (1998). The effect of teenage passengers on the fatal crash risk of teenage drivers. Accident Analysis and Prevention, 30, 217-222.

Raithel, J. (2003). Risikobezogenes Verhalten und Geschlechtsrollenorientierung im Jugendalter [Risk-taking behavior and gender role orientation in adolescents]. Zeitschrift für Gesundheitspsychologie, 11, 21-28. 
Reason, J. T., Manstead, A. S. R., Stradling, S., Baxter, J. S., and Campbell, K. (1990). Errors and violations on the roads: a real distinction? Ergonomics, 33, 1315-1332.

Rothe, J. P. (1987). Erlebnis of young drivers involved in injury producing crashes. In J. P. Rothe (Ed.), Rethinking young drivers (pp. 199-252). New Brunswick: Transaction.

Rowe, R., Maughan, B., and Goodman, R. M. (2004). Childhood psychiatric disorder and unintentional injury: findings from a national cohort study. Journal of Pediatric Psychology, 29, 119-130.

Rudman, L. A., and Goodwin, S. A. (2004). Gender Differences in Automatic In-Group Bias: Why Do Women Like Women More Than Men Like Men? Journal of Personality and Social Psychology, 87, 494-509.

Schmid Mast, M., Sieverding, M., Esslen, M., Graber, K., and Jäncke, L. (2008). Masculinity causes speeding in young men. Accident Analysis and Prevention, 40, 840-842.

Serbin, S. A., Powlishta, K. K., and Gulko, J. (1993). The development of sex typing in middle childhood. Monographs of the Society for Research in Child Development, 58, (2).

Shaver, K. G. (1985). The attribution of blame: Causality, responsibility, and blameworthiness. New-York, NY: Springer-Verlag.

Sibley, C. G., and Harré, N. (2009). A gender role socialization model of explicit and implicit biases in driving self-enhancement. Transportation Research Part F: Traffic Psychology and Behaviour, 12, 452-461.

Sidanius, J., Pratto, F., and Rabinowitz, J. L. (1994). Gender, ethnic status, and ideological asymmetry: A social dominance interpretation. Journal of Cross-Cultural Psychology, 25, 194-216.

Simon, F., and Corbett, C. (1996). Road traffic offending, stress, age, and accident history among male and female drivers. Ergonomics, 39, 757-780.

Social Issues Research Centre. (2004). Sex differences in driving and insurance risk. An analysis of the social and psychological differences between men and women that are relevant to their driving behaviour. In. Oxford: Social Issues Research Centre. 
Stangor, C., and Lange, J. E. (1994). Mental representation of social groups: Advances in understanding stereotypes and stereotyping. In M. P. Zanna (Ed.), Advances in Experimental Social Psychology (pp. 357-416). Hillsdale, NJ: Erlbaum.

Stoddart, K. (1987). Erfahrung of young drivers. In J. P. Rothe (Ed.), Rethinking young drivers (pp. 131-198). New Brunswick: Transaction.

Stoddart, T., and Turiel, E. (1985). Children's concepts of cross-gender activities. Child Development, 56, 1241-1252.

Sundström, A. (2008). Self-assessment of driving skill - A review from a measurement perspective. Transportation Research Part F: Traffic Psychology and Behaviour, 11, 1-9.

Tajfel, H., and Turner, J. C. (1986). The social identity theory in intergroup behavior. In S. Worchel and W. G. Austin (Eds.), Psychology of intergroup relations (2nd ed., pp. 7-24). Chicago: Nelson-Hall.

Taubman - Ben-Ari, O., Mikulincer, M., and Gillath, O. (2005). From parents to childrensimilarity in parents and offspring driving styles Transportation Research Part F: Traffic Psychology and Behaviour, 8, 19-29.

Tostain, M., and Lebreuilly, J. (2005). Essentialisme enfantin lié au genre et prise en compte de l'environnement social : Une étude auprès d'enfants de cinq à onze ans [Childhood essentialism about gender and the understanding of the social environment influence : A study involving five to eleven year old children]. Archives de psychologie, 71, 217-227.

Tronsmoen, T. (2008). Associations between self-assessment of driving ability, driver training and crash involvement among young drivers. Transportation Research Part F: Traffic Psychology and Behaviour, 11, 334-346.

Underwood, J., Dillon, G., Farnsworth, B., and Twiner, A. (2007). Reading the road: the influence of age and sex on child pedestrians' perceptions of road risk. British Journal of Psychology, 98, 93-110.

Walker, L., Butland, D., and Connell, R. W. (2000). Boys on the road : masculinities, car culture, and road safety education. The journal of men studies, 8, 153-169. 
Driving gender stereotypes among French preadolescents and adolescents

Wiberg, M. (2006). Gender differences in the Swedish driving-license test. Journal of Safety Research, 37, 285-291.

Yagil, D. (1998). Gender and age-related differences in attitudes toward traffic laws and traffic violations. Transportation Research Part F: Traffic Psychology and Behaviour, 1, 123135.

Yeung, N., and von Hippel, C. (2008). Stereotype threat increases the likelihood that female drivers in a simulator run over jaywalkers. Accident Analysis and Prevention, 40, 667-674.

Zemore, S. E., Fiske, S. T., and Kim, H.-J. (2000). Gender stereotypes and the dynamics of social interaction. In T. Eckes and H. M. Trautner (Eds.), The developmental social psychology of gender (pp. 207-241). London: Lauwrence Erlbaum Associates.

Zuckerman, M. (1991). Psychobiology of personality. Cambridge, England: Cambridge University Press. 
Appendix

\begin{tabular}{|c|c|c|c|}
\hline Topic & Categories & Characteristics & Spontaneous answers \\
\hline \multirow[t]{3}{*}{ Driving quality } & $\begin{array}{l}\text { Good } \\
\text { drivers }\end{array}$ & Drive well & Are good drivers / Know how to drive \\
\hline & \multirow[t]{2}{*}{ Bad drivers } & Drive poorly & Drive poorly / Don't know how to drive \\
\hline & & $\begin{array}{l}\text { Lack vehicle } \\
\text { control }\end{array}$ & $\begin{array}{l}\text { Don't know how to park / Lose control of } \\
\text { their vehicle / Can’t read maps }\end{array}$ \\
\hline \multirow[t]{7}{*}{$\begin{array}{l}\text { Behavior } \\
\text { related to safety }\end{array}$} & \multirow[t]{2}{*}{$\begin{array}{l}\text { Careful } \\
\text { drivers }\end{array}$} & Attentive & $\begin{array}{l}\text { Are careful / Pay attention / Are very } \\
\text { concentrated on what they are doing / Are } \\
\text { serious, are level-headed / Mind to speed } \\
\text { limits / Are afraid, worrier }\end{array}$ \\
\hline & & $\begin{array}{l}\text { Low } \\
\text { accidentology }\end{array}$ & $\begin{array}{l}\text { Have fewer accidents / Cause fewer } \\
\text { accidents }\end{array}$ \\
\hline & \multirow[t]{5}{*}{$\begin{array}{l}\text { Careless } \\
\text { drivers }\end{array}$} & Inattentive & $\begin{array}{l}\text { Are careless / Don't pay attention / Are } \\
\text { not concentrated, airheaded / Are not } \\
\text { responsible behind the wheel, carefree, do } \\
\text { stupid things / Selfish }\end{array}$ \\
\hline & & Aggressiveness & $\begin{array}{l}\text { Criticize other drivers / Lose their temper } \\
\text { behind the wheel, scream, gripe, are not } \\
\text { patient, toot their horn for no reason / } \\
\text { Insult other drivers / Are violent / Close } \\
\text { follow / Are in a hurry / Are too uptight, } \\
\text { stressed }\end{array}$ \\
\hline & & $\begin{array}{l}\text { High } \\
\text { accidentology }\end{array}$ & $\begin{array}{l}\text { Have more accidents, often risk having } \\
\text { accidents / Damage cars, have more minor } \\
\text { accidents / "Woman behind the wheel, } \\
\text { death around the corner"/ "Man driving, } \\
\text { accident arriving" }\end{array}$ \\
\hline & & Dangerousness & $\begin{array}{l}\text { Drive dangerously / Are not aware of } \\
\text { danger / Daredevil driver / Dangerous } \\
\text { passing }\end{array}$ \\
\hline & & $\begin{array}{l}\text { Lack of } \\
\text { concentration }\end{array}$ & $\begin{array}{l}\text { Play around / Chat / Sing, dance / Put on } \\
\text { make-up, fix their hair / Smoke / Listen to } \\
\text { loud music }\end{array}$ \\
\hline \multirow[t]{4}{*}{$\begin{array}{l}\text { Behavior } \\
\text { related to the } \\
\text { rules }\end{array}$} & \multirow[t]{3}{*}{$\begin{array}{l}\text { Compliant } \\
\text { drivers }\end{array}$} & $\begin{array}{l}\text { Comply with } \\
\text { the highway } \\
\text { code }\end{array}$ & $\begin{array}{l}\text { Comply with the highway code / Do not } \\
\text { get many tickets / Wear their seatbelts, } \\
\text { check that their children are buckled up / } \\
\text { Mind to speed limits }\end{array}$ \\
\hline & & Low speed & $\begin{array}{l}\text { Do not drive fast / Not fast enough / Too } \\
\text { slowly / Be passed }\end{array}$ \\
\hline & & $\begin{array}{l}\text { Avoid taking } \\
\text { psychotropic } \\
\text { drugs }\end{array}$ & $\begin{array}{l}\text { Avoid alcohol in the car / Drink less and } \\
\text { so have fewer accidents/ Never "stoned" } \\
\text { behind the wheel }\end{array}$ \\
\hline & $\begin{array}{l}\text { Offending } \\
\text { drivers }\end{array}$ & $\begin{array}{l}\text { Don't comply } \\
\text { with the } \\
\text { highway code }\end{array}$ & $\begin{array}{l}\text { Don't comply with the highway code / } \\
\text { Commit more traffic violations / Don’t use } \\
\text { their turn signals / Don't comply with } \\
\text { signs / Run red lights / Don't let } \\
\text { pedestrians cross / Park on pedestrian } \\
\text { crossings, in handicapped spaces / Don't }\end{array}$ \\
\hline
\end{tabular}


Driving gender stereotypes among French preadolescents and adolescents



